\title{
DIAGNOSA DAN PENATALAKSANAAN KARSINOMA NASOFARING
}

\author{
Suci Ariani*, Rachmat Belgi Saputra**, I Putu Sudiasa*** \\ Fakultas Kedokteran Universitas Islam Al-Azhar \\ J1. Unizar No.20 Turida Mataram
}

\begin{abstract}
ABSTRAK
Karsinoma Nasofaring (KNF) merupakan tumor ganas yang timbul pada epithelial pelapis ruangan dibelakang hidung (nasofaring) dengan predileksi yang paling sering adalah di fossa Rossen muller. Insidensi KNF tertinggi di Asia, Afrika Utara dan Timur Tengah. Penderita lebih banyak berjenis kelamin laki-laki. Di Indonesia KNF termasuk 5 besar keganasan bersama kanker serviks, kanker payudara, tumor ganas getah bening dan kanker kulit. Hampir $60 \%$ dari tumor di daerah kepala dan leher adalah KNF. Faktor risiko KNF secara umum dibagi menjadi 3, yaitu genetik, lingkungan dan virus Ebstein Barr. Untuk mengaktifkan Virus EBV dibutuhkan faktor pemicu lain untuk menimbulkan proses keganasan (Meka dan Mukhlis, 2017).
\end{abstract}

Kata Kunci : Karsinoma Nasofaring (KNF), Epithelial, Predileksi, Virus Ebstein Barr.

Tabel 1: Penentuan stadium dilakukan berdasarkan atas kesepakatan antara Union Internationale Centre Cancer (UICC) dan Americant Joint Committe on Cancer (AJCC).

\begin{tabular}{clr}
\hline $\begin{array}{l}\text { Keadaan } \\
\text { Tumor } \\
\text { Primer }(\mathrm{T})\end{array}$ & \\
\hline $\mathrm{T}_{\mathrm{x}}$ & Tumor primer tidak dapat \\
& dinilai \\
$\mathrm{T}_{0}$ & Tidak terdapat tumor \\
& primer \\
$\mathrm{T}_{\text {is }}$ & Karsinoma in situ \\
$\mathrm{T}_{1}$ & Tumor terbatas \\
& nasofaring/meluas \\
& orofaring dan/atau kavitas \\
& nasal, tanpa ekstensi \\
& parafaringeal \\
& Tumor meluas ke \\
$\mathrm{T}_{2}$ & parafaringeal \\
& Tumor masuk ke dalam \\
$\mathrm{T}_{3}$ & struktur tulang pada dasar \\
& tengkorak dan/atau sinus \\
& paranasal
\end{tabular}

$\mathrm{T}_{4} \quad$ Tumor dengan perluasan intracranial, hipofaring, orbita, atau fossa infratemporal

Kelenjar

getah

bening

regional

$(\mathrm{N})$

$\mathrm{N}_{\mathrm{x}} \quad$ KGB regional tidak dapat dinilai

$\mathrm{N}_{0} \quad$ Tidak terdapat metastasis ke KGB regional

$\mathrm{N}_{1} \quad$ Metastasis unilateral di KGB servikal, $\leq 6 \mathrm{~cm}$ di atas fossa supraklavikula atau keterlibatan KGB retrifaringeal bilateral atau unilateral, $<6 \mathrm{~cm}$ pada dimensi terbesarnya

$\mathrm{N}_{2}$ Metastasis bilateral di $\mathrm{KGB}, \leq 6 \mathrm{~cm}$ di atas fossa supraklavikula 
$\mathrm{N}_{3} \quad$ Metastasis di KGB ukuran $>6 \mathrm{~cm}$

$\mathrm{N}_{3 \mathrm{~A}} \quad$ Ukuran $>6 \mathrm{~cm}$

3B Perluasan ke fossa supraklavikula

Metastasis

jauh (M)

$\mathrm{M}_{\mathrm{x}} \quad$ Metastasis jauh tidak dapat dinilai

$\mathbf{M}_{1} \quad$ Tidak terdapat metastasis jauh

$\mathrm{M}_{2} \quad$ Metastasis jauh

Tabel 2 : Stadium Karsinoma Nasofaring

\begin{tabular}{|c|c|c|c|}
\hline Stadium & $\begin{array}{c}\text { Keadaan } \\
\text { tumor } \\
\text { primer } \\
(\mathrm{T})\end{array}$ & $\begin{array}{l}\text { KGB } \\
\text { region } \\
\text { al }(\mathrm{N})\end{array}$ & $\begin{array}{c}\text { Metast } \\
\text { asis } \\
\text { Jauh } \\
\text { (M) }\end{array}$ \\
\hline Stadium 0 & $\mathrm{~T}_{\text {is }}$ & $\mathrm{N}_{0}$ & $\mathrm{M}_{0}$ \\
\hline Stadium I & $\mathrm{T}_{1}$ & $\mathrm{~N}_{0}$ & $\mathrm{M}_{0}$ \\
\hline Stadium & $\mathrm{T}_{1}$ & $\mathrm{~N}_{1}$ & $\mathrm{M}_{0}$ \\
\hline \multirow[t]{2}{*}{ II } & $\mathrm{T}_{2}$ & $\mathrm{~N}_{0}$ & $\mathrm{M}_{0}$ \\
\hline & $\mathrm{T}_{2}$ & $\mathrm{~N}_{1}$ & $\mathrm{M}_{0}$ \\
\hline Stadium & $\mathrm{T}_{1}$ & $\mathrm{~N}_{2}$ & $\mathrm{M}_{0}$ \\
\hline \multirow[t]{4}{*}{ III } & $\mathrm{T}_{2}$ & $\mathrm{~N}_{2}$ & $\mathrm{M}_{0}$ \\
\hline & $\mathrm{T}_{3}$ & $\mathrm{~N}_{0}$ & $\mathrm{M}_{0}$ \\
\hline & $\mathrm{T}_{3}$ & $\mathrm{~N}_{1}$ & $\mathrm{M}_{0}$ \\
\hline & $\mathrm{T}_{3}$ & $\mathrm{~N}_{2}$ & $\mathrm{M}_{0}$ \\
\hline Stadium & $\mathrm{T}_{4}$ & $\mathrm{~N}_{0}$ & $\mathrm{M}_{0}$ \\
\hline \multirow[t]{2}{*}{ IV } & $\mathrm{T}_{4}$ & $\mathrm{~N}_{1}$ & $\mathrm{M}_{0}$ \\
\hline & $\mathrm{T} 4$ & $\mathrm{~N}_{2}$ & $\mathrm{M}_{0}$ \\
\hline Stadium & Semua & $\mathrm{N}_{3}$ & $\mathrm{M}_{0}$ \\
\hline IVA & $\mathrm{T}$ & & \\
\hline Stadium & Semua & Semua & $\mathrm{M}_{1}$ \\
\hline IVB & $\mathrm{T}$ & $\mathrm{N}$ & \\
\hline
\end{tabular}

Displasia merupakan lesi awal yang dapat terdeteksi yang diperkirakan dipengaruhi oleh beberapa karsinogen lingkungan. Area ini merupakan asal dari tumor namun belum cukup untuk menyebabkan perkembangan yang progresif. Pada stadium laten ini, infeksi EBV dapat memicu perkembangan displasia yang lebih berat (Asroel HA, 2002).

Tanda awal dari KNF sulit untuk dideteksi karena letak nasofaring yang tersembunyi (Adham dkk, 2012). Gejala dini diantaranya gejala telinga (tinitus, gangguan pendengaran, otitis media serosa), gejala hidung (epistaksis, sumbatan hidung). Gejala lanjut seperti pembesaran kelenjar limfe leher yang tidak nyeri. Gejala akibat perluasan tumor ke jaringan sekitar seperti gangguan beberapa saraf kranialis: kerusakan N.I (anosmia), paresis N.II (penurunan tajam penglihatan), paresis N.III (ptosis bulbi), paresis N.III, IV dan VI (diplopia), paresis N.V (neuralgia pada separuh wajah), N. IX, X, XI, dan XII (sindrom Jackson). Gejala akibat metastasis jauh (Meka dan Mukhlis, 2017).

Diagnosis KNF dapat ditegakkan melalui pemeriksaan nasofaring (kemungkinan besar tidak terlihat). Foto kepala dengan potongan anteroposterior dan lateral serta posisi Waters akan tampak jaringan lunak di daerah nasofaring dan foto toraks untuk melihat 
adanya metastase di paru-paru. CT-Scan kepala paling dipercayai untuk menetapkan diagnosis, staging tumor dan perluasan tumor. MRI dapat mendeteksi suatu sel keganasan yang tidak terlihat dengan endoskopi. Biopsi endoskopi bila seorang penderita memiliki tanda dan gejala KNF namun dari hasil pemeriksaan fisiknya tidak ditemukan adanya suatu kelainan. Darah rutin dan kimia darah untuk melihat status kesehatan penderita (American Cancer Society, 2015).

Tabel 3: Penatalaksanaan Sesuai Stadium (Soepardi, 2012)

\begin{tabular}{cc}
\hline Stadium & Penatalaksanaan \\
\hline Stadium I & Radioterapi \\
Stadium II & Kemoradiasi \\
$\&$ III & \\
Stadium & \\
IV dengan & Kemoradiasi \\
$\mathrm{N}<6 \mathrm{~cm}$ & \\
Stadium & Kemoterapi dosisi penuh \\
IV dengan & dilanjutkan dengan \\
$\mathrm{N}>6 \mathrm{~cm}$ & kemoradiasi \\
\hline
\end{tabular}

Penatalaksanaan utama karsinoma nasofaring sesuai stadium. Karsinoma nasofaring bersifat radioresponsif sehingga radioterapi tetap merupakan terapi terpenting. Radioterapi menggunakan sinar peng-ion untuk mematikan sel-sel tumor dan memelihara jaringan sehat di sekitar tumor agar tidak menderita kerusakan terlalu berat. Dosis radiasi perfraksi yang diberikan adalah
200 Gy DT (dosis tumor) diberikan 5 kali seminggu untuk tumor primer maupun kelenjar. Terapi radiasi biasanya dilakukan selama 3 minggu dengan menggunakan cisplatinum $100 \mathrm{mg} / \mathrm{m}^{2}$. Hasil pengobatan yang dinyatakan dalam angka respons terhadap penyinaran sangat tergantung pada stadium tumor. Makin lanjut stadium tumor, makin berkurang responsnya. Angka ketahanan hidup penderita karsinoma nasofaring tergantung stadium penyakit. Radiasi dapat menimbulkan komplikasi akut maupun kronik. Efek radiasi akut mencapai puncak dalam 90 hari. Pengaruh radiasi jangka panjang adalah kerusakan jaringan permanen. Pemberian kemoterapi pada karsinoma nasofaring diindikasikan pada kasus penyebaran ke KGB leher, metastasis jauh dan kasus-kasus residif. Diberikan sebagai kemoterapi neoadjuvan dan concomitan. Regimen kemoterapi neoadjuvan antara lain: cisplatin dan 5-FU, cisplatin dan epirubicin, paclitaxel dan carboplatin, docetaxel dan cisplatin, gemcitabin dan cisplatin (Farhat, 2009). Karena keterbatasan letak anatomi dan banyaknya kelenjar limfe maka terapi operatif jarang dilakukan.Pembedahan terbatas pada diseksi untuk mengontrol kelenjar yang radioresisten dan metastase leher setelah radioterapi (Basso, 2011).

\section{DAFTAR PUSTAKA}

Adham M, Kurniawan AN, Muhtadi AI, Roezin A, Hermani B, 
Gondhowiardjo S, et al. Nasopharyngeal carcinoma in Indonesia: epidemiology, incidence, signs, and symptomps at presentation. Chinese Journal of Cancer. 2012;31(4):185-96.

American Cancer Society.

Nasopharyngeal Cancer. Atlanta, Ga: American Cancer Society. 2015.

Asroel HA. 2002. Penatalaksanaan Radioterapi pada Karsinoma Nasofaring. Medan: USU Digital library [internet]; diakses 5 Mei 2018. Tersedia dari: http://repository.usu.ac.id/bitstream /handle/123456789/3463/ththary2.pdf;jsessionid=5D82BFECE 303B6E6EA80C254C9796F52?seq uence $=1$ carcinoma in a patient with early signs of unilateral ear disorder. Med J Indones. 2014; 23(1).

Basso S, Zecca M, Merli P, Gurrado A, Secondino S, Quartuccio G, et al. T Cell Therapy for Nasopharyngeal Carcinoma. Journal of Cancer. 2011;2:341-6.

Farhat. Vascular Endothelial Growth Factor pada Karsinoma Nasofaring. Majalah Kedokteran Nusantara. 2009;42(1):59-65.

Meka A. P. dan Mukhlis I. Tumor Nasofaring dengan Diplopia Pada Pasien Usia 44 Tahun. Volume 7. Nomor 4. Bagian THT-KL, Rumah Sakit Abdul Moeloek Provinsi Lampung. 2017: 181-6 